SŁAWOMIR SIKORA

Uniwersytet Warszawski

\title{
Przedwczesne pożegnanie
}

\author{
Komentarz do artykułu Michała Żerkowskiego, \\ Pożegnanie z terenem. Esej antropologiczny
}

ie chciałbym wcielać się w rolę Adama Kupera, który o pewnej książce
Clifforda Geertza powiedział, że powinno się ją zamknąc w szafie, by nie deprawowała studentów. Mam jednak wątpliwości dotyczące całego wywodu zawartego w artykule Pożegnanie z terenem. To interesujący i dobrze skonstruowany tekst, niemniej, moim zdaniem, zwodniczy i nie dający podstaw do wysnucia konkluzji: „porzucam Teren”. Autor sięga, co warto podkreślić, do różnych tropów literackich (np. Kafka, Soupault). Jednak przeskok między dawnymi wyobrażeniami (Malinowski i Griaule, o nadużyciach których nieco już powiedziano) a dawnymi i dzisiejszymi psychoanalitycznymi wywodami na temat fantazji (Freud, Lacan, Žižek) wydaje mi się zbyt "łatwy". Choć to ciekawy trop. Słuszna krytyka pewnych "sposobów postępowania" i pomysłów Malinowskiego czy Griaule’a (strój, perspektywa "odgórna") nie jest już dziś tak bardzo inspirująca. To nie jedyne przykłady, ale właśnie one wydają się retorycznie dominować w tekście. Autor równie dobrze mógłby przywołać tu zresztą np. Kirsten Hastrup - do której się odwołuje - bo mimo wielu zasług dla antropologii bywa ona dość „scjentystyczna”, a czasem także uprzedmiotawiająca. Może dałoby się wyszukać bardziej aktualne i zniuansowane przykłady dotyczące utożsamienia wiedzy/władzy $\mathrm{w}$ antropologii niż te wskazane w omawianym tekście. Pisanie o panoptyzmie w dobie stałego - choć, przyznam, często mało nośnego - przywoływania "punktu widzenia innego", wydaje się dziś równie mało przekonujące. Wywód zręcznie prześlizguje się po niektórych zagadnieniach: to często bardziej forma dowcipnego surfowania niż próba zanurzenia się $\mathrm{w}$ temacie (czy terenie), jak w przypadku stwierdzenia o tym, że człowiek/rozmówca jest dla nas przeszkodą terenową. Zabawne, ale czy na pewno prawdziwe? Szkoda, że Autor nie sięgnął po kilka świeższych, ważnych (!) przykładów z badań terenowych i nie zastanowił się, czy można na ich podstawie wyciągnąć takie wnioski, jakie sformułował. Może najlepiej 
byłoby odwołać się do własnego doświadczenia (czy też nieudanego doświadczenia?) terenowego. Przywołane w artykule (pogrzeb) raczej słabo do mnie przemawia. I wcale nie chcę nawracać Autora na teren. Ma prawo go porzucić...

„Porzucanie terenu" bywa zresztą dziś praktykowane, choć to raczej "teren" ulega znaczącej przemianie, o czym w tekście nie ma zbyt wiele (por. np. Cichocki 2012). Miałem zresztą odmienne przemyślenia w nawiązaniu do przytaczanego w komentowanym tekście twierdzenia Deborah D'Amico-Samuels i pointy Clifforda. Widziałbym tu raczej podobieństwo do myślenia o sacrum w koncepcji Eliadego: teren nie tyle jest wszędzie, ile wszędzie MOŻE zaistnieć... To podważa mocną konkluzję Clifforda (która wspiera się na opozycji logicznej: wszędzie/nigdzie, a ta, moim zdaniem, wcale nie jest wszechobowiązująca).

Teren dziś nie składa się z korkowego hełmu, białego stroju czy „oglądu z lotu ptaka" - zbyt wiele się wydarzyło, o czym Autor w ogóle nie wspomina. I nawet jeśli można przyznać mu (ograniczoną) rację co do zrównania fieldwork $\mathrm{z}$ battlefield, to wydaje mi się, że dziś owo „pole walki” jest zdecydowanie bardziej skomplikowane i niejednoznaczne... Już zwrot refleksyjny wprowadził wiele zmian i ocen krytycznych. George Marcus wraz z Douglasem Holmesem (2009) pokazują, że dziś trudno tę relację siły w badaniach (która w dyskursie zawsze potencjalnie istnieje) pojmować jednokierunkowo. Sherry Ortner (2009) wprowadza termin studing sideways (należy go rozumieć jako badania prowadzone wśród równych sobie, zajmowanie się ludźmi o podobnym statusie). Jeremy MacClancy redaguje książkę Exotic No More: Anthropology on the Front Lines (2002). Kilka dobrych przykładów można by jeszcze przytoczyć.

Stwierdzenie "opuszczam teren" rozczarowuje mnie również dlatego, że nie oferuje NIC $w$ zamian. Autor nie pisze przecież o porzuceniu antropologii w ogóle, co mogłoby być przykre, ale indywidualnie zawsze usprawiedliwione. Wysłanie wszystkich antropologów na przymusowe bezrobocie to może zbyt poważny "gest”.

Artykuł jest za mało natchniony, by stać się manifestem, jednocześnie omija, jak sądzę, różne ścieżki, którymi podążali dzieci i wnuki (i oczywiście wnuczki) Malinowskiego, a przecież warto je krytycznie zbadać, nim definitywnie rozstaniemy się z terenem... Niemniej tekst jest dobrze napisany (a to ważne), ponadto zaświadcza o pewnych uczuciach i niepokojach (co równie istotne), może też niewątpliwie dawać przesłanki do dalszych refleksji, również samemu Autorowi.

W humanistyce, ale też często w naukach społecznych - warto pamiętać - nie ma "obiektywnej racji”: raczej w kolejnych pomysłach, polemikach i sporach bywa ona kształtowana. To „tradycja (stale) wynajdywana”, nawet jeśli pewne "niezmienniki" wydają się trwać stale. Nauka to w końcu również zmieniająca się część naszej kultury. 


\section{Literatura}

Cichocki, P. (2012). Sieć przyjaciót: serwis społecznościowy oczami etnografa. Warszawa: Wydawnictwa Uniwersytetu Warszawskiego.

Holmes, D.R., Marcus, G.E. (2009). Przeformułowanie etnografii. Wyzwanie dla antropologii współczesności. Przeł. K. Miciukiewicz. W: N.K. Denzin, Y.S. Lincoln (red.), Metody badań jakościowych (t. II, s. 645-662). Warszawa: Wydawnictwo Naukowe PWN.

MacClancy, J. (ed.). (2002). Exotic No More: Anthropology on the Front Lines. Chicago: University of Chicago Press.

Ortner, S. (2009). Studying Sideways: Ethnographic Access in Hollywood. W: V. Mayer, M.J. Banks, J.T. Caldwell (eds.), Production Studies: Cultural Studies of Media Industries (s. 175-189), London: Routledge. 